\title{
Impact of Organic Manures and Bio-Fertilizers on Growth, Flowering, Fruiting, Yield and Quality of Tomato (Solanum lycopersicon Mill)
}

\author{
A.K. Singh ${ }^{*}$, Arun Kumar and P.K. Ray \\ RPCAU, Pusa, Samastipur- 848125 (Bihar), India \\ *Corresponding author
}

\section{A B S T R A C T}

\begin{tabular}{|l|}
\hline K e y w o r d s \\
FYM, Vermicompost, \\
Tomato, PSB, \\
Azospirillum, Bio- \\
fertilizers, Fruit yield, \\
Quality attributes
\end{tabular}

Keywords

\section{Introduction}

Tomato (Solanum lycopersicon Mill) is grown extensively throughout India for fresh consumption and commercial processing. Tomato varieties differ greatly in their growth and fruiting habits and are classified as determinate, semi determinate and indeterminate types. The main trailing stem of the indeterminate types grows to over $2.5 \mathrm{~m}$ long in warm climates, with vigorous side shoots. The shorter (semi-determinate) types and the bush (determinate) types stop growing earlier than the indeterminate, with the stem ending in a fruit truss. Indeterminate types are often preferred due to their prolonged bearing and higher yield potential.
Nowadays a lot of emphasis is placed on organic production of vegetables as it promotes ecological balance and conserves bio-diversity. Growers can reduce their production cost because they do not need to buy expensive chemicals and fertilizers.

Further organic produce is free from pesticide residues and thus healthier. Since organic produces have greater metabolic and structural integrity in their cellular structure than the conventional non-organic produce, they can be stored for a longer time. At present little information is available on use of only organic inputs for production of tomato in agroecological conditions of north Bihar. Therefore, the present work was undertaken to 
assess the impact of organic manures and biofertilizers on performance of tomato in this part of the country. Such information greatly helps in taking up further investigations for developing a precise organic farming schedule for the crop.

\section{Materials and Methods}

The experiment was conducted during Rabi season of 2014-15 at the Hi-tech Horticulture unit of RPCAU, Pusa. Geographically, this place is located at an altitude of $52 \mathrm{~m}$ between $25.98^{\circ} \mathrm{N}$ latitude and $85.67^{\circ} \mathrm{E}$ longitude and has humid sub-tropical climate. Variety "Abinash-2" was selected for the study. The plant of this variety has moderate foliage cover and indeterminate nature with prolific a uniform red colour at maturity.

The soil of the experimental plot was calcareous sandy loam with $\mathrm{pH}$ 8.4; EC 0.45 $\mathrm{mm}$ has $/ \mathrm{cm}$ at $25^{\circ} \mathrm{C}$, organic carbon 0.42 percent, available $\mathrm{P}_{2} \mathrm{O}_{5} 28.75 \mathrm{~kg} / \mathrm{ha}, \mathrm{K}_{2} \mathrm{O}$ $56.10 \mathrm{~kg} / \mathrm{ha}$ and free $\mathrm{CaCO}_{3} 30.2$ percent. The experiment was laid out in Factorial randomized block design with 12 treatments.

There were two factors viz. (I) Source of nutrients, and (II) bio-fertilizers. Under source of nutrients there were four treatments viz (I) use of recommended dose of inorganic fertilizers $\left(100 \mathrm{~kg} \mathrm{~N}, 50 \mathrm{~kg} \mathrm{P}_{2} \mathrm{O}_{5}\right.$ and $50 \mathrm{~kg}$ $\mathrm{K}_{2} \mathrm{O} / \mathrm{ha}$ ), (II) use of $15 \mathrm{t} \mathrm{FYM} \mathrm{/} \mathrm{ha,} \mathrm{(III)} \mathrm{use}$ of vermicompost @ 6 t/ha, and (IV) use of mustard cake @ 1/ha. In case of biofertilizers, three treatments viz. (I) PSB @ 2 $\mathrm{kg} / \mathrm{ha}$ (II) Azospirillum @ $5 \mathrm{~kg} / \mathrm{ha}$, and (III) combined use of PSB @ $2 \mathrm{~kg} / \mathrm{ha}$ and Azospirillum @ 5 kg / ha were tried along with the different sources of plant nutrients indicated above. The use of recommended NPK doses + combined use of PSB + Azospirillum were treated as control. All the treatments were replicated thrice following factorial RBD.
The land of the experimental site was irrigated site and was irrigated prior to sowing for optimum moisture level. Farm yard manure, vermin-compost and mustered cake were applied according to the treatments during the last ploughing along with the bio-fertilizers. The seedlings were transplanted at a spacing of $60 \times 45 \mathrm{~cm}$ and altogether 16 seedlings were accommodated in a plot of $1.80 \mathrm{~m} \times 2.40$ $\mathrm{m}$ size. Immediately after transplanting a light irrigation was given to avoid transplanting shock. First hand weeding was done at 15 days after transplanting to keep away the weeds. The second weeding was done at 45 days after the first weeding followed by hoeing. For managing insect pests a neem based pesticide was used thrice in all the treatments. Experiential data were collected from six randomly selected plants from in treatment in a replication. The data of plant height, branches per plant, number of days to first flowering, number of flower per plant, number of fruit per plant, fruit weight $(\mathrm{g})$, fruit yield (q/ha), total soluble solids $\left(\mathrm{TSS}^{0}\right.$ Brik), and ascorbic acid (vitamin $\mathrm{C} \mathrm{mg/100} \mathrm{g),} \mathrm{were}$ recorded to assess the impact of the treatments. The data were analyzed using analysis of variance (ANOVA) under Factorial randomized block design following the procedure as stated by Panse and Sukhatme (1985).

\section{Results and Discussion}

It is obvious from the results that the treatments had significant positive effect on increase in plant height (Table 1). Application of vermicompost $6 \mathrm{t} / \mathrm{ha}$ and PSB $2 \mathrm{~kg} / \mathrm{ha}+$ Azospirillum $5 \mathrm{~kg} / \mathrm{ha}$ had the tallest plants as compared to the control i.e. inorganic NPK application. This treatment was significantly superior than the rest of the treatments. It is also apparent than use of vermicompost $6 \mathrm{t} / \mathrm{ha}$ and PSB $2 \mathrm{~kg}+$ Azospirillum $5 \mathrm{~kg} / \mathrm{ha}$ produced the highest number of branches per plant. The lowest number of branches was 
recorded in the control treatment were inorganic fertilizers were used.

The number of days to first flowering is depicted in Table 2 which indicated that the number of days required for blooming was the highest when vermicompost was used along with bio-fertilizers. However, use of mustard cake produced statistically similar results and plants took almost similar duration for flowering as application of N, P, K and FYM. Application of inorganic fertilizer induced plants to flower early as compared to other treatments. Number of flowers per plant was observed to be significantly higher in case of combined application of vermicompost and the two bio-fertilizers. Application of straight fertilizers produced significantly lower number of flowers per plant.

However, the impact of organic manures was more pronounced in regulating the onset of flowering in tomato. The effect of biofertilizers was not apparent in this regard (Table 2) but the combined effect of sources of nutrient and bio-fertilizer were statistically significant.

The source of supply of nutrients and biofertilizers had significant impact on productivity of the plants. Number of fruits per plant was significantly higher in case of organic sources of nutrients than the inorganic sources or the control (Table 3). Plants produced, the highest number of fruits when vermicompost was used along with the two bio-fertilizers. Application of mustard cake or FYM resulted in lower number of fruits per plant. Combined use of bio fertilizers exhibited better results than their solitary use (Table 3).

Fruit yield varied significantly due to the treatments. Organic sources of nutrients produced markedly better yields than that of the inorganic fertilizers in the control treatment. Similarly bio-fertilizers also have positive impact on yield. The best yield was obtained when vermicompost @ 6 t/ha was used along with PSB @ $2 \mathrm{~kg}+$ Azospirillum @ $5 \mathrm{~kg} / \mathrm{ha}$. Solitary use of bio-fertilizers produced lower yields than their combined use. Similarly, application of NPK fertilizers resulted in significantly lower fruit yield than all the organic manures used in the trial (Table 4). Fruit quality attributes like fruit weight, TSS and ascorbic acid content also varied significantly due to the treatments. Plants getting vermicompost and the two bio fertilizers produced fruits with significantly higher TSS content.

Use of PSB alone brought lower TSS content in fruits that of Azospirillum. Use of NPK fertilizers with bio fertilizers did not bring any improvement in the TSS content as compared to the organic sources of nutrients (Table 4).

Ascorbic acid content of fruits was little lower when vermicompost was used as the source of nutrients to the plants. In fact, there was no significant impact of the two factors considered in isolation but their combined effect has marked influence on the ascorbic acid content of the fruits. Vermicompost along with bio-fertilizers brought significant reduction in ascorbic acid content than the use of NPK fertilizers with PSB and Azospirillum (Table 5).

The results presented in the preceding paragraphs clearly indicated that the use of vermicompost along with bio-fertilizers like PSB and Azospirillum had pronounced beneficial impact on vegetative growth, fruit yield and quality of tomato under agroecological conditions of north Bihar. In this experiment vermicompost proved to be the most effective organic source of plant nutrients and also a powerful growth promoter over the conventional compost (FYM), mustard cake and inorganic N P K fertilizers. 
Table.1 Effect of organic manure and bio-fertilizers on vegetative characters of Tomato cv. Abinash - 2

\begin{tabular}{|c|c|c|c|c|c|c|c|c|c|c|}
\hline \multirow[t]{2}{*}{ Treatment } & \multicolumn{5}{|c|}{ Plant height (cm) } & \multicolumn{5}{|c|}{ Number of branches / plant } \\
\hline & $\begin{array}{c}\text { Control } \\
\text { (NPK: kg/ha) } \\
(100: 50: 50)\end{array}$ & $\begin{array}{c}\text { FYM@ } \\
\text { t/ha }\end{array}$ & $\begin{array}{c}\text { Vermi @ } \\
\text { 6t/ha }\end{array}$ & $\begin{array}{c}\text { M. cake } \\
1 \text { t/ha }\end{array}$ & Mean & $\begin{array}{c}\text { Control } \\
\text { (NPK: kg/ha) } \\
(100: 50: 50)\end{array}$ & $\begin{array}{c}\text { FYM } \\
\text { @15 t / } \\
\text { ha }\end{array}$ & $\begin{array}{c}\text { Vermi @ } \\
\text { 6t/ha }\end{array}$ & $\begin{array}{c}\text { M. cake } \\
1 \mathrm{t} / \mathrm{ha}\end{array}$ & Mean \\
\hline PSB @ 2 kg/ha & 145.50 & 185.20 & 221.25 & 175.65 & 181.90 & 3.50 & 5.50 & 7.50 & 6.35 & 5.71 \\
\hline $\begin{array}{l}\text { Azos.@5 } \\
\text { kg/ha }\end{array}$ & 150.60 & 193.43 & 235.70 & 182.42 & 190.53 & 4.00 & 6.10 & 8.15 & 6.70 & 6.23 \\
\hline $\begin{array}{l}\text { PSB } 2 \mathrm{~kg}+ \\
\text { Azos. } 5 \mathrm{~kg} / \mathrm{ha}\end{array}$ & 165.50 & 205.15 & 245.50 & 190.40 & 201.63 & 4.75 & 6.80 & 9.25 & 7.10 & 6.97 \\
\hline \multirow[t]{2}{*}{ Mean } & 153.86 & 194.59 & 234.15 & 182.81 & - & 4.08 & 6.13 & 8.30 & 6.71 & - \\
\hline & $\mathbf{A}^{*}$ & $\mathbf{B}^{*}$ & $\mathbf{A} \times \mathbf{B}^{*}$ & & & $\mathbf{A}^{*}$ & B* & $A \times B^{*}$ & & \\
\hline $\mathrm{SE}(\mathrm{m}) \pm$ & 5.52 & 4.78 & 9.57 & & & 0.15 & 0.13 & 0.27 & & \\
\hline CD (0.05) & 16.20 & 14.03 & 28.07 & & & 0.46 & 0.40 & 0.81 & & \\
\hline $\mathrm{CV} \%$ & 8.66 & & & & & 7.58 & & & & \\
\hline
\end{tabular}

$* \mathrm{~A}=$ Source of nutrients $; * \mathrm{~B}=$ Biofertilizers; $* \mathrm{~A}$ x B $=$ Interaction between $\mathrm{A}$ and $\mathrm{B}$

Table.2 Effect of organic manure and bio-fertilizers on flowering and fruiting characters of tomato cv. Abinash -2

\begin{tabular}{|c|c|c|c|c|c|c|c|c|c|c|}
\hline \multirow[t]{2}{*}{ Treatment } & \multicolumn{5}{|c|}{ Day to flowering (days) } & \multicolumn{5}{|c|}{ Number of flower / plant } \\
\hline & $\begin{array}{c}\text { Control } \\
\text { (NPK: kg/ha) } \\
(100: 50: 50)\end{array}$ & $\begin{array}{c}\text { FYM @15 } \\
\text { t/ha }\end{array}$ & $\begin{array}{c}\text { Vermi @ } \\
\text { 6t/ha }\end{array}$ & $\begin{array}{c}\text { M. } \\
\text { cake } 1 \\
\text { t/ha }\end{array}$ & Mean & $\begin{array}{c}\text { Control } \\
\text { (NPK: kg/ha) } \\
(100: 50: 50)\end{array}$ & $\begin{array}{c}\text { FYM @ } 15 \\
\text { t/ha }\end{array}$ & $\begin{array}{c}\text { Vermi @ } \\
\text { 6t/ha }\end{array}$ & $\begin{array}{c}\text { M. } \\
\text { cake } 1 \\
\text { t/ha }\end{array}$ & Mean \\
\hline PSB @ 2 kg/ha & 35.50 & 36.40 & 42.50 & 37.50 & 37.97 & 22.50 & 32.25 & 37.46 & 31.70 & 30.97 \\
\hline $\begin{array}{l}\text { Azos. @5 } \\
\text { kg/ha } \\
\end{array}$ & 36.00 & 37.70 & 43.10 & 41.00 & 39.45 & 25.50 & 34.45 & 43.81 & 33.50 & 34.31 \\
\hline $\begin{array}{l}\text { PSB 2kg + } \\
\text { Azos. 5kg /ha }\end{array}$ & 37.10 & 39.70 & 48.25 & 45.40 & 42.61 & 28.15 & 38.50 & 47.90 & 38.80 & 38.33 \\
\hline \multirow[t]{2}{*}{ Mean } & 36.20 & 37.93 & 43.66 & 42.25 & - & 25.38 & 35.06 & 43.06 & 34.66 & - \\
\hline & $\mathbf{A}^{*}$ & B* & $\mathbf{A} \times \mathbf{B}^{*}$ & & & $\mathbf{A}^{*}$ & B* $^{*}$ & $\mathbf{A} \times \mathbf{B}^{*}$ & & \\
\hline $\mathrm{SE}(\mathrm{m}) \pm$ & 2.17 & 1.88 & 3.76 & & & 1.98 & 1.72 & 3.44 & & \\
\hline CD (0.05) & 6.37 & NS & 11.05 & & & 5.82 & 5.04 & 10.09 & & \\
\hline CV \% & 13.40 & & & & & 14.25 & & & & \\
\hline
\end{tabular}

* A = Source of nutrients; * B = Biofertilizers; *A x B = Interaction between A and B

Table.3 Effect of organic manure and bio-fertilizers on fruit characters of tomato cv.

Abinash - 2

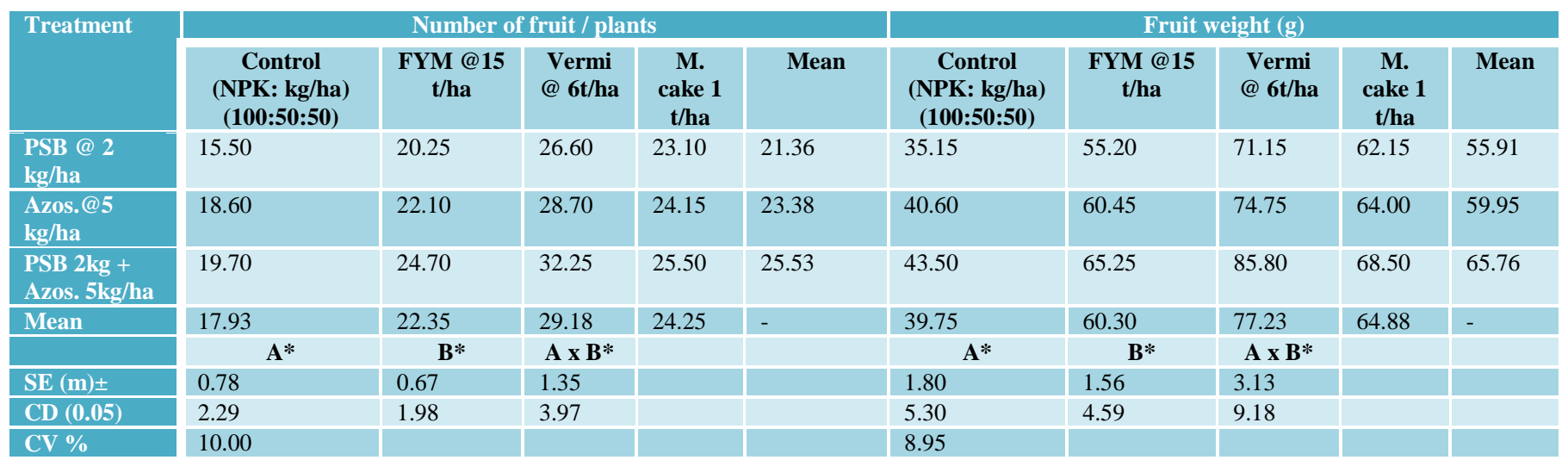

* A = Source of nutrients; * B = Biofertilizers; *A x B = Interaction between A and B 
Table.4 Effect of organic manure and bio-fertilizers on fruit yield and quality of Tomato cv. Abinash - 2

\begin{tabular}{|c|c|c|c|c|c|c|c|c|c|c|}
\hline \multirow[t]{2}{*}{ Treatment } & \multicolumn{5}{|c|}{ Fruit yield g/ha } & \multicolumn{5}{|c|}{ Total soluble solid ( ${ }^{0}$ Brick) } \\
\hline & $\begin{array}{c}\text { Control } \\
\text { (NPK: kg/ha) } \\
(100: 50: 50)\end{array}$ & $\begin{array}{c}\text { FYM } \\
@ 15 \text { t/ha }\end{array}$ & $\begin{array}{c}\text { Vermi @ } \\
\text { 6t/ha }\end{array}$ & $\begin{array}{c}\text { M. cake } \\
1 \text { t/ha }\end{array}$ & Mean & $\begin{array}{c}\text { Control } \\
\text { (NPK: kg/ha) } \\
(100: 50: 50)\end{array}$ & $\begin{array}{c}\text { FYM @ } 15 \\
\text { t/ha }\end{array}$ & $\begin{array}{l}\text { Vermi } \\
\text { @ 6t/ha }\end{array}$ & $\begin{array}{c}\text { M. } \\
\text { cake } 1 \\
\text { t/ha }\end{array}$ & Mean \\
\hline $\begin{array}{l}\text { Azos.@5 } \\
\text { kg/ha }\end{array}$ & 281.00 & 496.30 & 788.89 & 574.07 & 535.01 & 3.47 & 4.25 & 5.00 & 4.50 & 4.30 \\
\hline $\begin{array}{l}\text { PSB 2kg + } \\
\text { Azos. } 5 \mathrm{~kg} / \mathrm{ha}\end{array}$ & 318.00 & 596.30 & 1022.22 & 648.15 & 646.29 & 3.55 & 4.60 & 5.45 & 4.70 & 4.57 \\
\hline Mean & $\mathbf{A}^{*}$ & $\mathbf{B}^{*}$ & $A \times B^{*}$ & & & $\mathbf{A}^{*}$ & B* & $\mathbf{A} \times \mathbf{B}^{*}$ & & \\
\hline $\mathrm{SE}(\mathrm{m}) \pm$ & 18.29 & 15.84 & 31.69 & & & 0.13 & 0.12 & 0.24 & & \\
\hline CD (0.05) & 53.67 & 46.48 & 92.96 & & & 0.41 & 0.35 & 0.71 & & \\
\hline $\mathrm{CV} \%$ & 10.02 & & & & & 9.73 & & & & \\
\hline
\end{tabular}

* $\mathrm{A}=$ Source of nutrients; * B = Biofertilizers; *A x B = Interaction between A and B

Table.5 Effect of organic manure and bio-fertilizers on fruit quality and B: C ratio of Tomato cv. Abinash - 2

\begin{tabular}{|c|c|c|c|c|c|c|c|c|c|c|}
\hline \multirow[t]{2}{*}{ Treatment } & \multicolumn{5}{|c|}{ Ascorbic acid (mg/100 g) } & \multicolumn{5}{|c|}{ B: C Ratio } \\
\hline & $\begin{array}{c}\text { Control } \\
\text { (NPK: kg/ha) } \\
(100: 50: 50)\end{array}$ & $\begin{array}{l}\text { FYM } \\
@ 15 \\
\text { t/ha }\end{array}$ & $\begin{array}{l}\text { Vermi } \\
\text { @ 6t/ha }\end{array}$ & $\begin{array}{c}\text { M. } \\
\text { cake } 1 \\
\text { t/ha }\end{array}$ & Mean & $\begin{array}{c}\text { Control } \\
\text { (NPK: kg/ha) } \\
(100: 50: 50)\end{array}$ & $\begin{array}{l}\text { FYM } \\
@ 15 \\
\text { t/ha }\end{array}$ & $\begin{array}{c}\text { Vermi @ } \\
\text { 6t/ha }\end{array}$ & $\begin{array}{c}\text { M. cake } \\
1 \text { t/ha }\end{array}$ & Mean \\
\hline $\begin{array}{l}\text { PSB @ } 2 \\
\text { kg/ha } \\
\end{array}$ & 26.20 & 24.25 & 22.75 & 24.85 & 24.51 & 1.60 & 4.14 & 5.40 & 4.97 & 4.02 \\
\hline $\begin{array}{l}\text { Azos.@5 } \\
\text { kg/ha }\end{array}$ & 25.10 & 23.50 & 22.50 & 24.10 & 23.58 & 2.34 & 4.96 & 6.12 & 5.35 & 4.69 \\
\hline $\begin{array}{l}\text { PSB 2kg + } \\
\text { Azos. 5kg/ha }\end{array}$ & 24.65 & 23.15 & 22.10 & 23.65 & 23.52 & 2.65 & 5.96 & 7.90 & 6.04 & 5.63 \\
\hline \multirow[t]{2}{*}{ Mean } & 25.31 & 23.63 & 22.45 & 24.20 & & 2.19 & 5.02 & 6.47 & 5.45 & \\
\hline & $\mathbf{A}^{*}$ & $\mathbf{B}^{*}$ & A $\times$ B* & & & $\mathbf{A}^{*}$ & B* & $\mathbf{A} \times \mathbf{B}^{*}$ & & \\
\hline $\mathrm{SE}(\mathrm{m}) \pm$ & 1.31 & 0.65 & 0.75 & & & 0.140 & 0.121 & 0.243 & & \\
\hline CD (0.05) & NS & NS & 2.22 & & & 0.411 & 0.356 & 0.712 & & \\
\hline CV\% & 9.50 & & & & & 8.795 & & & & \\
\hline
\end{tabular}

* A = Source of nutrients; * B = Biofertilizers; *A x B = Interaction between A and B

According to Sinha et al., (2009) vermicompost works as a soil conditioner and its application leads to total improvement in the quality of soil. They further asserted that with its use nitrogen and other nutrients in the soil tend to be released at constant rate from the accumulated 'humus' and the net overall efficiency of NPK over a period of years is considerably greater than $50 \%$ of that of chemical fertilizers.

Arancon and Edward (2011), and Singh et al., (2014) have reported that vermicompost contained growth promoting hormones like auxin, cytokinins, gibberellins. The growth responses of plants from vermicompost appears from more like "hormone - induced activity" associated with high levels of humic acids and humates in vermicompost rather than boosted by high levels of plant available nutrients (Tomati et al., 1988). Atiyeh et al., (2002) found that humic acid isolated from vermicompost enhanced root elongation and formation of more lateral roots and root hairs in the plants thereby increasing the nutrient uptake by the plants. The better performance of tomato crop in this experiment with vermicompost can be attributed to these characteristics of the earthworm cast used to grow the crop as source of plant nutrients. 
Many reports are available to show better efficacy of organic sources of plant nutrients over inorganic ones in tomato production (Shukla et al., 2006, Azami et al., 2008; Patil et al., 2005; Patil et al., 2010; Gosavi et al., 2010; Gajbhiye et al., 2010). In this experiment vermicompost with two biofertilizers proved to be the most efficient combination. FYM or Mustard cake used with the two bio-fertilizers did not produce superior results in terms of vegetative growth or productivity (yield) of tomato. This might be due to differences in the loading of nutrients to the experimental soil by these materials. Suhane (2007) asserts that vermicompost is at least 4 times more nutritive than cattle dung compost.

Mustard cake has higher levels of N, P, K per unit mass than FYM or vermicompost but it is the costliest of all the organic sources of plant nutrients tried here. Mustard cake has $4.8 \%$ nitrogen, $2.0 \% \mathrm{P}_{2} \mathrm{O}_{5}$ and $1.3 \% \mathrm{~K}_{2} \mathrm{O}$ (Swati et al., 2015). Since the quantity of mustard cake used was 1 tonne per hectare, the quantum of nutrients supplied to the soil was lower as compared to that of vermicompost or FYM. This might be the reason for lower performance of plants with this treatment. However, mustard cake has an ideal balance of methionine and other amino acids. So its application helps the plants in de novo synthesis of methionine that supports protein synthesis in later stages or growth. Here in this experiment the quality of tomato fruit was at par statistically when vermicompost or mustard cake was applied. The mustard cake is slow in mineralizing but gaseous nitrogen losses are much smaller in comparison to $\mathrm{NO}_{3}$ fertilizers. However Ullah et al., (2008) reported that although organic fertilizers maintained good health of soil but they were slow to release adequate nutrients timely and thus recommended combined application of nutrients through both inorganic and organic sources.
According to Boydston et al., (2008) several breakdown products of glucosinolate in mustard cake have pesticidal properties, including weed suppression capacity. These researchers documented the efficacy of mustard cake as bio-pesticide to control weeds in ornamental plants. Here observation related to weed count was not made and weeding was done uniformly for all the treatments, but there exists every possibility of lower crop - weed competition in use of mustard cake. Nevertheless, use of mustard cake with bio-fertilizers produced marginally higher number of fruits per plant and also showed little improvement in respect to individual fruit weight (Table 3). But in terms of fruit yield per hectare basis, application of mustard cake produced significantly better results than FYM application. This was due to cumulative effect of the treatment in a wider perspective taking into account chemical properties of the cake, its mineralization in the soil and utilization by the plants.

Cost-benefit analysis clearly indicated significant gains in economic terms with use of vermicompost and two bio-fertilizers use of inorganic fertilizer showed the list benefit amongst all the treatments due to poor fruit yield. The best treatment i.e. vermicompost + PSB + Azospirillum produced the highest B: $C$ ratio of 7.9 and thus proved to be most remunerative among all the treatments (Table $5)$.

On the basis of results presented above it is concluded that use of organic sources of nutrients e.g. FYM, vermicompost and mustard cake and bio-fertilizers like PSB and Azospirillum is helpful in boosting tomato productivity in calcareous soil of north Bihar.

For best performance of indeterminate tomato varieties soil application of vermicompost @ 6 t/ha along with PSB $2 \mathrm{~kg}+$ Azospirillum 5 $\mathrm{kg} / \mathrm{ha}$ can be recommended. 


\section{References}

Arancon, N. and Edwards, Clive A. (2011) The use of vermicompost as soil Amendments for production of field crops, in vermiculture technology (Eds. Edwards, Clive A; Arancon, N.Q and Sherman, Rhonda), CRC Press, Boca Ratan, Florida, USA pp 103 - 128

Atiyeh, R.M; C.A Lee Edward; N.Q. Arancon and J.D. Metzger (2002) The influence of hurmic acids derived from earthworm processed organic wastes on plant growth, Bioresource Technology 84: 7 - 14.

Azami, R. Mousa Torabi Giglou and Rahim Didar Taleshmikail (2008) Influence of vermicompost on soil chemical and physical properties in tomato (Lycoperssicum esculentum) field. African J. Biotechnology, 7 (14): 2397 2001.

Boydston, R.A: Andersan, T. and Vaughn, S.F (2008) Mustard (Sinapsis alba) seed meal suppresses weeds in container grown ornamentals, Hort. Sci. 43 (3): $800-803$

Gajbhiye, R.P; Sharma, R.R; Tewari, R.N; Sureja, A.K (2010): Effect of inorganic and bio - fertilizers on fruit quality of tomato. Indian Journal of Horticulture. 67 (Special Issue): 301 - 304

Gosavi, P U; Kamble, A B; Pandure, B.S (2010): Effect of organic manures and biofertilizers on quality of tomato fruits. Asian Journal of Horticulture 5 (2): 376 $-378$

Gosavi, P U; Kamble, A.B; Pandure, B.S (2010): Effect of organic manures and biofertilizers on quality of tomato fruits. Asian Journal of Horticulture. 5 (2): 376 - 378

Gosavi, P.U; Kamble, A.B; Pandure, B.S (2010): Effect of organic manures and biofertilizers on quality of tomato fruits.
Asian Journal of Horticulture. 5 (2): 376-378

Holger Hesse; Oliver Kreft. S. Maimann; M. Zeh and R. Hoefgen (2004) current understanding of regulation of methionine biosynthesis in plants, $\mathbf{J}$ Expt. Bot. 139: 1799-1808.

Panse, V.G. and Sukhatme, P.V. (1985). Statistical methods for Agricultural workers, ICAR, New Delhi

Patil, D.N; Bhalekar, M.N; Dhumal, S.S; Shinde, U.D; Kshirsagar, D.B (2010): Effect of organic manures and biofertilizers on growth and yield of tomato. Journal of Maharashtra Agricultural Universities; 35 (3): 396 399.

Patil, D.N; Bhalekar, M.N; Dhumal, S.S; Shinde, U.S; Kshirsagar, D.B (2010): Effect of organic manures and biofertilizes on growth and yield of tomato. Journal of Maharashtra Agricultural Universities; 35 (3): 396 399.

Patil, O.H; Chavan, S.D; Patil, M B; Gadambe, B.G; Bhosale, A.M (2005): Use of bioenzymes in enhancing yield and quality of tomato (Lycopersicon esculentum Mill.) Horticultural Journal, 18 (1): 56 - 58

Patil, O.H; Chevan, S.D; Patil, M.B; Gadambe, B.G; Bhosale, A.M (2005): Use of bioenzymes in enhancing yield and quality of tomato (Lycopersicon esculentum Mill) Horticultural Journal, 18 (1): 56 - 58.

Prasad, V.K; Das K.S; Dashrath Yadav (2002): Effect of biofertilizer and different levels of fertilizer on growth, yield and quality of tomato (Lycopersicon esculentum Mill) Bioved 13 (1/2): 125 - 127.

Shukla, Y.R; Thakur, A.K; Joshi (2006): Effect of inorganic and organic fertilizers on yield and horticultural traits in tomato (Lycopersicon 
esculentum Mill.). Annais - of-Biology: 22 (2) 137 - 141.

Singh, Keshav; Gorakh Nath; R.C. Shukla, and D.K. Bhartiya (2014): A textbook of Vermicompost; Vermiwash and Biopesticides; Astral International, New Delhi pp 97.

Sinha, R; Heart; Sunil. Valani Dalsukhbhai and Chauhan Krunalkumar (2009) earthworms vermicompost: A powerful crop nutrient over the conventional compost and protective soil conditioner against the destructive chemical fertilizers for food safety and security. Am. Euras J. Agric \& Environ Sci. 5 (5): $01-55$.
Suhane, R.K. (2007) vermicompost (in Hindi). Pub. of Rajendra Agricultural University, Pusa, India pp 88

Swati; Sneha Sehwag and Madhusweta Das (2015) A brief review: Present status on utilization of mustard oil and cake, Indian Journal of Traditional Knowledge 14 (2): 244 - 250.

Tomati, V; A. Grappelli and E. Galli (1988) The hormone like effect of earthworm casts on plant growth. Biology and Fertility of soils, 5: 288 - 294

Ullah, M.S; Islam, M.S; Islam, M.A and Haque, T. (2008) Effect of organic manures and chemical fertilizers on the yield of brinajl and soil properties. J. Bangladesh Agr. Univ. 6 (2) 271 - 276.

\section{How to cite this article:}

Singh, A.K., Arun Kumar and Ray, P.K. 2018. Impact of Organic Manures and Bio-Fertilizers on Growth, Flowering, Fruiting, Yield and Quality of Tomato (Solanum lycopersicon Mill). Int.J.Curr.Microbiol.App.Sci. 7(10): 2180-2187. doi: https://doi.org/10.20546/ijcmas.2018.710.250 